Original research article

\title{
Knowledge and self-assessment of general practitioner nurses in the area of diabetes mellitus
}

\author{
Pavla Kudlová ${ }^{1 *}$, Ilona Kočvarová ${ }^{2}$ \\ ${ }^{1}$ Tomas Bata University in Zlín, Faculty of Humanities, Department of Health Care Sciences, Zlin, Czech Republic \\ ${ }^{2}$ Tomas Bata University in Zlín, Faculty of Humanities, Research Centre, Zlín, Czech Republic
}

\begin{abstract}
In general practitioners' offices (GPOs), nurses care for patients with diabetes mellitus (DM), too.

Goal: Our goal was to find the amount of knowledge and the level of self-assessment of nurses in GPOs in connection to persons with $\mathrm{DM}$, and to analyze the relationships between the dependent variable (overall level of knowledge about DM) and selected independent variables.

Methods: The cross-sectional study was conducted on a sample of nurses in 2018. A 64-item questionnaire was used to collect the data; a part of which was a standardized Rev. Diabetes Knowledge Test (revDKT). Within the data analysis, regression analysis was conducted in exploratory regime.

Results: A total of 237 nurses (working in GPOs) took part in the study (average age $38 \pm 10.6$ ). Within the analysis, the overall level of selfassessment was taken as a mean from 25 items assessed on a scale of 1-5; the smaller the value, the more positive the self-assessment. In our case the mean was 3.35. Within the analysis, the overall level of general knowledge of DM was taken as a sum of points from a total of 33 knowledge items (43 points max). The respondents averaged 22 points, which represents a $51 \%$ success rate on the test. A college education (either three or five years) had the greatest influence on the overall level of knowledge.

Conclusions: There are nurses with varying professional qualifications, education, and job titles working in GPOs. The self-assessment and overall knowledge score connected to DM of the groups being compared (practical nurses and other) is rather low. To increase the competencies of nurses in GPOs, it is necessary to inform general practitioners of nurse categories, and ensure further education of nurses in the area of DM.
\end{abstract}

Keywords: Category; Diabetes mellitus; General practitioners' offices; Knowledge; Nurse; revDKT; Self-Assessment

\section{Introduction}

General practical medicine is a fundamental subject in the Czech Republic that ensures medical and preventative care for the whole population from the age of 15 or 19 (Býma et al., 2014). The main workers of which are general practitioners (GP) and nurses, or other health care professionals (e.g. physiotherapists, nutritional therapists, etc.), and non-medical workers (e.g. receptionists) (Býma et al., 2014; Seifert et al., 2013; Vojtíšková, 2006). The main goal of a GP is to provide citizens with medical and health care that corresponds to the current scientific findings (Karen and Svačina, 2018). Responsibility for creating a network of medical services lies mainly with health insurance companies in collaboration with the Society of General Practice of the Czech Medical Association of J. E. Purkyně (GP CzMA JEP), the Association of General Practitioners of the Czech Republic (AGP CZ), and the Czech Medical Chamber (CMC). The spectrum of medical services provid- ed by the GP and paid for by public health insurance is very wide, but this is still not comparable to GP's working in other EU countries (Býma et al., 2014).

Patients with DM should be treated in facilities or at workplaces that can provide treatment at the proper level - depending on the type of diabetes and its severity, in compliance with recommended standard processes (ADA, 2019; Davies et al., 2018). Treatment and dispensarization of a patient with Type 2 DM is provided by general practitioners or diabetologists (Karen and Svačina, 2018; Pelikánová and Bartoš, 2018; Škrha et al., 2017). The most important tasks of a GP in connection the management of DM are prevention of Type $2 \mathrm{DM}$, identification of patients with a high risk of Type 2 DM, and early diagnosis of DM. Another important task is the decision to commence treatment or handing the patient over to dispensary care (respecting the patient's right to free choice of physician), or treatment of noncomplicated patients with Type 2 DM with the possibility of consulting with a physician in their catchment diabetological office (Karen and Svačina, 2018; La-

\footnotetext{
* Corresponding author: Pavla Kudlová, Tomas Bata University in Zlín, Faculty of Humanities, Department of Health Care Sciences, Štefánikova 5670, 760 01, Zlín, Czech Republic; e-mail: kudlova@utb.cz

http://doi.org/10.32725/kont.2020.031

Submitted: 2020-05-10 • Accepted: 2020-08-24 • Prepublished online: 2020-08-25 
Salle and Berria, 2013). Definition of competencies and rules of collaboration between general practitioners and specialists is governed by the Journal of the Ministry of Health of the Czech Republic 8/2010 from July 1, 2010 (hereinafter Journal 8/2010), and by the recommended processes of Prediabetes and Diabetes designated for general practitioners (Karen and Svačina, 2016; 2018; Karen et al., 2019). Reform of primary care has been implemented in recent years by the Health Department of the Czech Republic in collaboration with general practitioners and health insurance companies. The goal of the reform is to increase the competencies and strengthen the role of general practitioners, among others in the area of care for persons with diabetes and pre-diabetic persons, as is already specified in Reimbursement Ordinance for 2020 (Šonka and Býma, 2019).

As mentioned by Býma et al. (2014): "The work of a GP is, in our conditions, based on collaboration with a nurse." In respect to his/her significant position on the team, it is necessary for a nurse to possess a postgraduate education. This education is mainly ensured by the National Center of Nursing and Health Care Disciplines is Czech) in Brno, or the Czech Nurse Association, and GP CzMA JEP, AGP CZ and other institutions (Býma et al., 2014). There are nurses with various degrees of professional qualification; namely registered nurses, practical nurses, midwives and pediatric nurses that have - in compliance with the regulations - very different qualification and post-qualification competences (Public Notice 391/2017 Coll.; Act 96/2004 Coll., as amended, etc.). General practitioners are mostly unaware of this fact.

A cross-sectional study was designed in order to find and analyze the current level of preparedness of nurses from GP offices (in terms of knowledge).

\section{Goal}

Our goal was to find the level of knowledge and self-assessment in relation to diabetes mellitus by comparing groups of GP nurses. Another goal was to assess the influence of overall self-assessment, age, length of practice in the health care industry, qualifications and education, current work position, daily contact with diabetic persons, and the number of persons with diabetes they have treated during their practice on the overall level of general knowledge.

\section{Materials and methods}

\section{Methods and characteristics of the respondents}

Based on intentional selection, a total of 237 nurses working in primary outpatient care were involved in the study (without regard to the respondents' gender). The respondents were assured that the survey was anonymous, and were asked not to distort data while filling out the test. They were also informed in advance that by filling out and submitting the questionnaire they consent to its processing.

The questionnaire had a total of 68 items and consisted of four parts. Part 1 was focused on sociodemographic data of the respondents: age, education, qualification, education focused on diabetology or a similar area, length of practice in medical care, current vs. correct work position in a GP's surgery. Part 2 contained 25 items focused on the respondents' self-assessment in the area of knowledge and skills connected to nursing care for persons with DM. The items were created in collaboration with a psychologist and special pedagogue. Part 3 contained a standardized 23-item Diabetes Knowledge Test (DKT), developed, validated and published by the Mich- igan Diabetes Research Training Center (MDRTC) in 1998 to discover general knowledge of diabetes mellitus (Fitzgerald et al., 1998, pp. 52-65). The DKT contains 14 general knowledge items designated for people with Type 1 and 2 DM (T1 DM and T2 DM), and 9 items designated for people taking insulin as treatment (Fitzgerald et al., 1998). The DKT was revised in 2015 (revDKT, Fitzgerald et al., 2016). The questionnaire is freely available, the only condition being quoting the original authors. Another 10 semi-opened items have been added to the revDKT in order to assess the knowledge of the participants of a certified course focued on nursing care and education in diabetology (Kudlová et al., 2017).

530 (10\%) offices of general practitioners were addressed out of the total 5,331 in the Czech Republic (see National Health Care Information System - NHCIS, 2018); and the questionnaire return rate was $45 \%$.

Regression analysis was conducted within data analysis, the goal of which was to monitor the relationship between the dependent variable (overall level of knowledge of diabetes mellitus) and selected independent variables. This analysis was realized in exploratory regime with emphasis placed on values of material significance (therefore the results cannot be generalized).

\section{Results}

The average age of the respondents was 38 years $(38 \pm 10.6$ SD, min. 23, max. 66). All the respondents declared they had had more than one year of practice in the health care area. $12050.6 \%$ ) of them declared a practice of up to 15 years, and 117 (49.4\%) declared over 15 years of practice. A total of 181 respondents $(76 \%)$ declared that they had achieved high school education, and 56 (24\%) college education (23 at bachelor's level and 12 at master's level), or higher professional education (HPE) (in total 21).

The respondents declared that they currently worked at general practitioners' offices. A total of 172 (76\%) respondents work as registered nurses (RN) without any specialization, $34(14 \%)$ as nurses, $28(12 \%)$ as practical nurses (PN), $3(1 \%)$ as specialized registered nurses (SRN), and 1 as a pediatric nurse (PdN). However, the correct division based on the nurses' education was supposed to be this: $\mathrm{RN}$ without a specialization 197 (83\%), SRN 3 (1\%), PN 34 (14\%), another two non-significant groups were formed by 2 midwives and 1 pediatric nurse. For the purposes of our analysis the respondents were divided into two work categories: RN (200, i.e. $84 \%)$ and other [PN, PdN, MdW - 37 (16\%)].

The respondents stated the actions they most often performed on diabetic persons (Table 1). Most often (100\%) they perform administrative duties and measure physiological functions. In $96 \%$ of cases they measure glycemia in persons with diabetes. 47 (20\%) of the respondents stated that they had little contact with persons with diabetes in general practitioners' offices, 62 (26\%) daily, and 128 (54\%) often.

105 (44\%) of the respondents declared that they had dealt with more than 100 persons with diabetes in their career.

$100 \%$ of the respondents stated that they had drawn information on diabetes mellitus from their qualification studies. 38 (16\%) stated that diabetology was one of the subjects they studied during their qualification studies. From the offer of lifelong education the respondents mostly chose courses and seminars $(50 \%)$, self-study (40\%), and conferences and symposiums (39\%). Certified courses or specializations were chosen the least frequently (17\%). 


\section{Table 1. Nursing activities (\% choosing given option)}

\begin{tabular}{lcc} 
& $N$ & $\%$ \\
\hline a) application of insulin & 237 & 42 \\
b) measuring glycemia & 237 & 96 \\
c) taking blood & 237 & 89 \\
d) administration of antidiabetics & 237 & 35 \\
e) treating a defect/wound & 237 & 69 \\
f) prevention of diabetic foot & 237 & 45 \\
g) working with insulin pump & 237 & 0 \\
h) education in terms of diet & 237 & 49 \\
i) wider education & 237 & 21 \\
j) diabetic foot care & 237 & 0 \\
k) measuring physiological functions & 237 & 100 \\
l) administrative duties & 237 & 100 \\
m) dispensarization & 237 & 28 \\
n) other & 237 & 0 \\
\hline
\end{tabular}

Part 2 of the questionnaire contained 25 items focused on the level of self-assessment on a 5-point Likert scale ( $1=$ excellent level, 5 = very bad level) of general knowledge and skills of nurses relating to nursing care for persons with DM. Registered nurses have a slightly more positive self-assessment than the other groups, i.e. the lower the average, the more positive the self-assessment (Table 2).

Part 3 of the questionnaire was focused on establishing the level of general knowledge of diabetes mellitus using the revDKT (which contains 23 selected items primarily aimed at patients), and 10 semi-opened items regarding nursing care, created within partial and final assessment of the Nursing Care and Education in Diabetology certified course participants (Kudlová et al., 2017).

It was possible to achieve a maximum of 23 points for 23 closed items. It was possible to achieve a maximum of 10 points for 10 open items.

The total level of general knowledge was the sum of the points for all 33 items. It was theoretically possible to achieve 0-43 points. The respondents achieved $7-40$ points, and 22 points on average, which is a $51 \%$ success rate on the test.

Registered nurses had slightly better results in the four areas of knowledge than other nurses (Table 3):

Table 2. Comparing groups of registered nurses and others in self-assessment

\begin{tabular}{|c|c|c|c|c|c|c|c|c|}
\hline & \multicolumn{8}{|c|}{ 5b. Correct work position -2 categories } \\
\hline & \multicolumn{4}{|c|}{ Other } & \multicolumn{4}{|c|}{ Registered nurses } \\
\hline & Mean & Minimum & Maximum & $\begin{array}{l}\text { Standard } \\
\text { deviation }\end{array}$ & Mean & Minimum & Maximum & $\begin{array}{l}\text { Standard } \\
\text { deviation }\end{array}$ \\
\hline Overall self-assessment & 3.46 & 2.28 & 4.52 & 0.55 & 3.33 & 1.76 & 4.76 & 0.50 \\
\hline $\begin{array}{l}\text { Q1 Self-assessment: (Self)management } \\
\text { of diabetes and education }\end{array}$ & 3.45 & 2.33 & 4.83 & 0.61 & 3.21 & 1.50 & 4.67 & 0.50 \\
\hline $\begin{array}{l}\text { Q2 Self-assessment: Insulin therapy, } \\
\text { pharmacotherapy and education }\end{array}$ & 3.49 & 2.33 & 4.33 & 0.50 & 3.38 & 1.83 & 4.83 & 0.54 \\
\hline $\begin{array}{l}\text { Q3 Self-assessment: Lifestyle, diet, and } \\
\text { education }\end{array}$ & 3.41 & 2.00 & 4.50 & 0.53 & 3.45 & 1.50 & 4.83 & 0.60 \\
\hline $\begin{array}{l}\text { Q4 Self-assessment: Diagnostics and } \\
\text { treatment of complications including } \\
\text { education }\end{array}$ & 3.50 & 1.57 & 4.43 & 0.73 & 3.28 & 1.57 & 4.71 & 0.55 \\
\hline
\end{tabular}

Table 3. Comparison of the knowledge of registered nurses and other nurses (PN, MdW, PdN)

\begin{tabular}{|c|c|c|c|c|c|c|c|c|}
\hline & \multicolumn{8}{|c|}{ Work position of nurses -2 categories } \\
\hline & \multicolumn{4}{|c|}{ Other } & \multicolumn{4}{|c|}{ Registered nurses } \\
\hline & Mean & Minimum & Maximum & $\begin{array}{l}\text { Standard } \\
\text { deviation }\end{array}$ & Mean & Minimum & Maximum & $\begin{array}{l}\text { Standard } \\
\text { deviation }\end{array}$ \\
\hline $\begin{array}{l}\text { Q1 Knowledge: (Self)management of } \\
\text { diabetes and education }\end{array}$ & 3.59 & 1.00 & 8.00 & 1.85 & 5.55 & 2.00 & 10.00 & 1.91 \\
\hline $\begin{array}{l}\text { Q2 Knowledge: Insulin therapy, } \\
\text { pharmacotherapy and education }\end{array}$ & 3.43 & 1.00 & 9.00 & 1.50 & 5.26 & 1.00 & 11.00 & 1.93 \\
\hline $\begin{array}{l}\text { Q3 Knowledge: Lifestyle, diet, and } \\
\text { education }\end{array}$ & 4.05 & 2.00 & 6.00 & 1.15 & 4.77 & 1.00 & 10.00 & 1.74 \\
\hline $\begin{array}{l}\text { Q4 Knowledge: Diagnostics and } \\
\text { treatment of complications including } \\
\text { education }\end{array}$ & 6.89 & 3.00 & 10.00 & 1.66 & 7.36 & 3.00 & 10.00 & 1.78 \\
\hline $\begin{array}{l}\text { Q3 Knowledge: Lifestyle, diet, and } \\
\text { education }\end{array}$ & 4.05 & 2.00 & 6.00 & 1.15 & 4.77 & 1.00 & 10.00 & 1.74 \\
\hline $\begin{array}{l}\text { Q4 Knowledge: Diagnostics and } \\
\text { treatment of complications including } \\
\text { education }\end{array}$ & 6.89 & 3.00 & 10.00 & 1.66 & 7.36 & 3.00 & 10.00 & 1.78 \\
\hline
\end{tabular}


We also conducted regression analysis focused on establishing the relationship between the overall level of general knowledge (dependent variable) and independent variables.

Dependent variable: overall level of general knowledge (the sum of points for a total of 33 knowledge items). The respondents acquired 22 points on average, which means a $51 \%$ success rate on the test.

Independent variables:

1. The overall level of self-assessment (the mean for 25 items evaluated on a scale of $1-5$, where the lower the value, the more positive the self-assessment). The resulting values ranged between 1.76 and 4.76 (3.35 on average).

2. Age (23-66 years of age, 38 on average).

3. Length of practice in health care (for the purposes of our analysis simplified to two categories: less than 15 and more than 15 years). There were 120 (51\%) respondents in the first category, and 117 (49\%) in the latter.

4. Qualification education (for the purposes of our analysis simplified to two categories: high school education/other, and HPE (nursing college)/college education. 56 (24\%) respondents declared a higher professional education (nursing college), all of the others declared high school or other.

5. The current work positions of the respondents (for the purposes of our analysis simplified to two categories: registered nurses without a specialization and the others. There were 200 (84\%) registered nurses (both specialized and without specialization), and 37 (16\%) others.

6. Daily contact with persons with diabetes: 62 respondents (26\%); the others had less frequent contact with them.

7. More than 100 persons with diabetes treated during their practice to date: 105 respondents (44\%).

It was the classic multiple linear regression method Enter. Model ( $F=8.707 ; \mathrm{df}=7 ; p \leq 0.005)$ is characterized by the overall amount of explained variation $21 \%$ (using the coefficient $R^{2}$; in adjusted form then 19\%). The resulting model is presented in Table 4.

Table 4. Regression analysis of the relationship between the overall level of general knowledge (dependent variable) and independent variables

\begin{tabular}{|c|c|c|c|c|c|c|c|}
\hline & \multicolumn{2}{|c|}{$\begin{array}{l}\text { Nonstandardized } \\
\text { coefficients }\end{array}$} & \multirow{2}{*}{$\begin{array}{c}\text { Sandardized } \\
\text { coefficients } \\
\text { Beta }\end{array}$} & \multirow[t]{2}{*}{$\mathrm{T}$} & \multirow[t]{2}{*}{ Sig. } & \multicolumn{2}{|c|}{ Collinearity statistics } \\
\hline & B & Std. Error & & & & Tolerance & VIF \\
\hline (Constant) & 23.153 & 3.006 & & 7.703 & 0.000 & & \\
\hline Overall self-assessment & -2.094 & 0.731 & -0.185 & -2.864 & 0.005 & 0.829 & 1.206 \\
\hline Age & 0.104 & 0.058 & 0.192 & 1.810 & 0.072 & 0.306 & 3.272 \\
\hline Length of practice more than 15 years & 1.505 & 1.139 & 0.131 & 1.321 & 0.188 & 0.352 & 2.838 \\
\hline College/Nursing college (HPE) education & 4.327 & 1.004 & 0.319 & 4.310 & 0.000 & 0.628 & 1.591 \\
\hline RN without a specialization & 0.468 & 1.163 & 0.030 & 0.403 & 0.687 & 0.602 & 1.660 \\
\hline Daily contact with patients with diabetes & -1.003 & 0.874 & -0.077 & -1.148 & 0.252 & 0.775 & 1.290 \\
\hline $\begin{array}{l}\text { Having treated more than } 100 \text { persons with } \\
\text { diabetes }\end{array}$ & 0.312 & 0.790 & 0.027 & 0.395 & 0.693 & 0.742 & 1.347 \\
\hline
\end{tabular}

First we will focus on the values of nonstandardized Beta coefficients. It transpired that the overall level of knowledge is slightly affected by the overall level of self-assessment, which is a rather unexpected result. However, this was also verified within the analysis by using another method (classic correlation analysis). The respondents who declared daily contact with persons with diabetes, also had a slightly lower overall level of knowledge (however, only very slightly). The other variables in the model have positive values, so it is possible to say that within this group of 237 nurses the overall level of knowledge was positively influenced by older age, length of practice over 15 years, college education or HPE (nursing college), being a registered nurse without a specialization, and the estimated number of treated persons with diabetes being over 100. However, all the values in the model are low, and it is not possible to say that one of them was of special significance.

Using standardized Beta coefficients it is possible to compare the level of influence of individual variables in the model. College or nursing college education (HPE) clearly has the strongest influence on the overall level of knowledge. The influence of the other variables seems to be rather small.

The values focused on checking multicollinearity in the model are within the norm (the tolerance is in all cases $>0.2$; VIF (variance inflation factor) is in all cases <10).

\section{Discussion}

Diabetes mellitus (DM) is a disease that affects not only the patients themselves, but also their loved ones. It also has an impact on the health and social care system. DM is a very frequent disease in the Czech Republic. In 2017 there were a total of 936,124 persons diagnosed with DM in the Czech Republic, with an incidence of 11 new cases per 1,000 people in the population. The most frequent form is Type $2 \mathrm{DM}$ (84\%), with every seventh inhabitant of the Czech Republic suffering from this disease (NZIS, 2018, p. 2).

A growing number of patients with DM and a limited stagnating number of diabetology outpatient wards have led to defining an algorithm of collaboration in the care for patients with Type 2 DM among specialized diabetology outpatient wards and general practitioners' offices (Journal of Ministry of Health of the Czech Republic 8/2010).

Modern practice applied by general practitioners requires the transfer of some competences from the physician to the nurse (Býma et al., 2014). Registered nurses in general practitioners' offices provide nursing care within the scale of their expertise. They help with screening, prevention, diagnostics, therapy, and education. They ensure nursing care, visiting ser- 
vice, administrative work, and psychological assistance to the patients. They are co-responsible for a flawless and smooth operation of the office, which includes ensuring all the necessary material for treatment. They help with diagnostics, treatment, and education of patients with T2 DM (Rybka et al., 2006; Vojtíšková, 2006). Nurses, not only those in general practitioners' offices, are expected to overtake more competences in education in the area of health support and primary, secondary and tertiary prevention. This, however, mainly depends on their skills and knowledge (Bastable, 2008). However, it is necessary to realize that nurses' competences are limited and must comply with regulations (see Act 96/2004 Coll. and Decree 55/2011 Coll.). Practical nurses have smaller competences than registered nurses (see Decree 391/2017 Coll.). General practitioners are mostly not aware of this fact. In their opinion, all nurses have the same education and competences.

To ensure quality nursing care in general practitioners' offices it is necessary to have well educated nurses with competences that will enable them to provide quality nursing care to patients with DM in compliance with the latest findings. The reason for our research was the fact that there have been no research studies conducted in the $C R$ that would provide us with valid data in this area. Only a small study by Turlichová and Kafková (2007) carried out on a sample of 36 nurses concerns knowledge of nurses from general practitioners' offices, in which the authors claimed that $58 \%$ of the nurses felt they lacked professional knowledge.

Nurses in our study achieved 22 points on average within the DM knowledge test, which is a $51 \%$ success rate. That, however, is insufficient in respect to the desired increasing of nurses' competences. We also found that college or nursing college (HPE) education has the greatest influence on the overall level of knowledge. The influence of the other variables is relatively small. Foreign authors dealing with knowledge of nurses in primary care are for example: Daly et al. (2019), Livingston and Dunning (2010), Hollis et al. (2014) or Haugstvedt et al. (2016). The results were also insufficient.

So the question is how to provide registered nurses with adequate knowledge for quality and safe nursing care for a DM client. In a longitudinal study (2010-2014) by Kudlová et al. (2017), 88 participants of a five-year HDCR - accredited course were subject to continual and final testing in diabetology. All the respondents failed the entrance test in diabetology (27-40\% success rate). Again, qualification education of the persons being tested was not an issue (physician, nurse, midwife). However, there was a significant increase of knowledge in the results of all the evening tests and the final test too (92.5 to $98.8 \%$ of the maximum possible knowledge level). On the contrary, the results of the repeated final tests (after each three months and in 2018) had a declining tendency. The authors assume that the decline in knowledge was caused by inadequate adoption of knowledge by the respondents (Kudlová et al., 2019). However, other studies that have proven education increases the knowledge score are available too (e.g. Hearnshaw et al., 2004; Rubin et al., 2007). A possible solution to the current situation is to include the subject of diabetol- ogy among compulsory/optional subjects within qualification studies, and also to create an educational program in the form of a certified course that would correspond to the practice and scope of work of registered nurses. This form of education is also supported by the Czech Medical Association of J. E. Purkyně (Býma et al., 2014).

\section{Conclusions}

Currently, there are nurses with various professional qualifications and specializations working in general practitioners' offices, who have inadequate knowledge in the area of diabetes mellitus ( $51 \%$ on average). In respect to the need to increase their competences in the area of care for persons with DM, it is necessary to bring their knowledge and skills up to date by means of qualification and lifelong education. It is necessary to give some thought to the possibilities of nurse education in this area. It is also necessary to redefine personal standards (correct categories of nurses and the description of their work activities) within general practitioners' offices. Only in this way can we improve the quality of care within primary care.

\section{Limitations of the study}

The questionnaires were only filled out by those nurses whose results may contribute to increased quality of nursing care for patients with diabetes mellitus in general practitioners' offices. A limitation of the study is that the research set does not meet the requirements for representativeness (as it was realized as an intentional, not representative selection). That is why the results cannot be generalized for the whole population of Czech nurses who work in general practitioners' offices. Another limitation is the relatively small size of the research set, which resulted in the need to simplify the categories of variables being monitored within regression analysis into two categories (e.g. a/ daily contact with persons with diabetes, and $\mathrm{b}$ / less frequent contact). Having a larger number of categories would make the model more complicated and decrease its quality. Despite all the above limitations it is possible to consider the results as unique in the Czech context.

\section{Ethics and consent}

The study was approved by the relevant committee. All the respondents were informed of their voluntary participation in the research study.

\section{Conflict of interests}

The authors have no conflicting interests. With support from the project: RVO/FHS/2020/005 Multidisciplinary Approaches to Health and Illness.

\section{Acknowledgements}

We would like to thank all the nurses from general practitioners' offices for their support and collaboration in filling out the questionnaires. 


\section{Znalosti a sebehodnocení sester z ordinací praktických lékařů v oblasti diabetu mellitu}

\section{Souhrn}

V ordinacích všeobecných praktických lékařů (VPL) sestry ošetřují i osoby s diabetem mellitem (DM).

Cíl: Naším cílem bylo zjistit míru znalostí a úroveň sebehodnocení sester z ordinací VPL souvisejících s péčí o osoby s DM a analyzovat vztahy mezi závisle proměnnou (celková úroveň znalostí o DM) a vybranými nezávisle proměnnými.

Metodika: Průřezová studie byla realizována na výběrovém vzorku sester v roce 2018. Ke sběru dat byl použit 64položkový dotazník, jehož součástí byl standardizovaný Rev. Diabetes Knowledge Test (revDKT). V rámci analýzy dat byla dále realizována regresní analýza v exploračním režimu.

Výsledky: Studie se zúčastnilo 237 sester (průměrný věk $38 \pm 10,6$ let) z ordinací VPL. Celková úroveň sebehodnocení byla v rámci analýzy pojata jako průměr z 25 položek hodnocených na škále 1-5, čím nižší hodnota, tím pozitivnější sebehodnocení, v našem případě s průměrem 3,35 . Celková úroveň všeobecných znalostí DM byla v rámci analýzy pojata jako součet bodů z celkem 33 znalostních položek (max. 43 bodů). Respondenti získali průměrně 22 bodů, což je $51 \%$ úspěšnost v testu. Jednoznačně největší vliv na celkovou míru znalostí má získané vysokoškolské nebo vyšší odborné vzdělání.

Závěr: V ordinacích VPL pracují sestry s různou profesní kvalifikací, vzděláním a pracovním zařazením. Sebehodnocení a celkové vědomostní skóre týkající se DM komparovaných skupin (VS a ostatní) je spíše nízké. Vzhledem k avizovanému navýšení kompetencí sester v ordinaci VPL je třeba seznámit VPL s kategoriemi sester a zajistit další vzdělání sester v oblasti DM.

Klíčová slova: diabetes mellitus; ordinace VPL; revDKT; sebehodnocení; sestra; znalost

\section{References}

1. Act $96 / 2004$ Coll., on the conditions of acquiring and acknowledgement of eligibility to perform nonmedical health care professions, and to perform activities relating to providing health care, and on changes to some related laws (Act on Nonmedical Health Care Professions)]. In: Sbírka zákonů České republiky, částka 30/2004. [online] [cit. 2019-03-28]. Available from: https://www.zakonyprolidi.cz/cs/2004-96

2. ADA (2019). Lifestyle Management: Standards of Medical Care in Diabetes - 2019. Diabetes Care 42(Suppl. 1): S46-S60. DOI: $10.2337 / \mathrm{dc} 19-S 005$.

3. Bastable SB (2008). Nurse as educator: Principles of Teaching and Learning for Nursing Practice. Ontario, Sudbury: Jones and Bartlett Publishers.

4. Býma S, Seifert B, Šmatlák V, Štolfa J (2014). Koncepce oboru všeobecné praktické lékařství. [Conception of the field of general practical medicine]. Prakt Lék 94(1): 3-9.

5. Daly BM, Aroll B, Scragg RKR (2019). Diabetes knowledge of primary health care and specialist nurses in a major urban area. J Clin Nurs 28(1-2): 125-137. DOI: 10.1111/jocn.14684.

6. Davies MJ, D’Alessio DA, Fradkin J, Kernan WN, Mathieu C, Mingrone G, et al. (2018). Management of hyperglycaemia in type 2 diabetes, 2018. A consensus report by the American Diabetes Association (ADA) and the European Association for the Study of Diabetes (EASD). Diabetologia 61(12): 2461-2498. DOI: $10.1007 / \mathrm{s} 00125-018-4729-5$.

7. Decree 391/2017 Coll., on the competences of health care professionals and other professionals]. [online] [cit. 2019-0328]. Available from: https://www.zakonyprolidi.cz/cs/2017-391

8. Fitzgerald JT, Funnell MM, Hess GE, Barr PA, Anderson RM, Hiss RG, Davis WK (1998). The reliability and validity of a brief diabetes knowledge test. Diabetes Care 21(5): 706-710. DOI: 10.2337/diacare.21.5.706.

9. Fitzgerald JT, Funnel MM, Anderson RM, Nwankwo R, Stantsfield RB, Piatt GA (2016). Validation of the Revised Brief Diabetes Knowledge Test (DKT2). Diabetes Educ 42(2): 178-187. DOI: 10.1177/0145721715624968.

10. Haugstvedt A, Aarflot M, Ingland J, Landbakk T, Graue M (2016). Diabetes knowledge in nursing homes and home-based care services: a validation study of the Michigan Diabetes Knowledge Test adapted for use among nursing personnel. BMC Nurs 15: 40. DOI: 10.1186/s12912-016-0159-1.

11. Hearnshaw H, Hopkins J, Hudges N, Dale J (2004). A model of effective distributed delivery to healthcare professionals of education in diabetes care. Educ Prim Care 15(4): 596-605.
12. Hollis M, Glaister K, Lapsley JA (2014). Do practice nurses have the knowledge to provide diabetes self-management education? Contemp Nurse 46(2): 234-41. DOI: 10.5172/ conu.2014.46.2.234

13. Journal of Ministry of Health of the Czech Republic 8/2010]. [online] [cit. 2019-03-28]. Available from: https:// www.mzcr.cz/wp-content/uploads/wepub/4025/36348/ V\%C4\%9Bstn\%C3\%ADk\%20MZ\%20\%C4\%8CR\%208-2010.pdf

14. Karen I, Svačina Š (2016). Prediabetes - novelizace 2016. [Prediabetes - as amended in 2016]. [online] [cit. 2020-05-15]. Available from: https://www.svl.cz/files/files/Doporucenepostupy-od-2013/Prediabetes-2016.pdf

15. Karen I, Svačina Š (2018). Diabetes mellitus - novelizace 2018. [Diabetes mellitus - as amended in 2018]. [online] [cit. 2020-05-15]. Available from: https://www.svl.cz/files/files/ Doporucene-postupy/2017/DP-DM-2018.pdf

16. Karen I, Svačina Š, Jurášková B (2019). Diabetes mellitus léčba u starších pacientů v ČR. [Diabetes mellitus - treatment of older patients in the Czech Republic]. [online] [cit. 2020-05-15]. Available from: https://www.svl.cz/files/files/Doporucenepostupy/2017/DM-u-starsich-pac-2019.pdf

17. Kudlová P, Chlup R, Zapletalová J (2017). The benefits of postgraduate therapeutic education in diabetology in the Czech Republic. EpSBS 30: 217-227. DOI: 10.15405/ epsbs.2017.09.20.

18. Kudlová P, Chlup R, Zapletalová J, Olecká I (2019). Continual and final testing within postgraduate course in diabeotology. In: ICERI 2019 Proceedings. Valencia: IATED Academy, pp. 908-917.

19. LaSalle JR, Berria R (2013). Insulin Therapy in Type 2 Diabetes Mellitus: A Practical Approach for Primary Care Physicians and Other Health Care Professionals. J Am Osteopath Assoc 113(2): 152-62. PMID: 23412677.

20. Livingston R, Dunning T (2010). Practice nurses' role and knowledge about diabetes management within rural and remote Australian general practices. EDN 7(2): 55-62. DOI: 10.1002/ edn.158.

21. NZIS REPORT No. K/17 (08/2018). Zdravotnictví ČR: Stručný přehled činnosti oboru praktický lékař pro dospělé 2007-2017. Brief outline of the field of general practitioner for adults 2007-2017]. [online] [cit. 2020-05-20]. Available from: https:// www.uzis.cz/sites/default/files/knihovna/nzis_rep_2018_K17_ A040_prakticky_lekar_pro_dospele_2017.pdf

22. Pelikánová T, Bartoš V (2018). Praktická diabetologie. [Practical diabetology]. 6th updated and amended ed. Praha: Maxdorf.

23. Rubin DJ, Moshang J, Jabbour SA (2007). Diabetes knowledge: are resident physicians and nurses adequately prepared to 
manage diabetes? Endocr Pract 13(1): 17-21. DOI: 10.4158/ EP.13.1.17.

24. Rybka J, et al. (2006). Diabetologie pro sestry. [Diabetology for Nurses]. Praha: Grada.

25. Seifert B, Beneš V, Býma $S$ (2013). Všeobecné praktické lékařství. [General practitioners']. 2nd suppl. and amended ed. Praha: Galén.

26. Škrha J, Pelikánová T, Kvapil M (2017). Doporučený postup péče o diabetes mellitus 2. typu. [Recommended procedure of care for (patients with) diabetes mellitus]. [online] [cit. 2020-04-05]. Available from: http://www.diab.cz/dokumenty/standard_ lecba_dm_typ_II.pdf
27. Šonka P, Býma S (2019). Koncepce změn primární péče v ČR. Materiál Pracovní skupiny pro reformu primární péče. [The concept of changes in primary care in the Czech Republic. Material of the Working Group for Primary Care Reform]. [online] [cit. 2020-05-14]. Available from: https://www.lkcr.cz/ aktuality-322.html?do[loadData]=18itemKey=cz_99853

28. Turlichová M, Kafková J (2007). Studie „Sestra v ordinaci PL“. [Study "Nurse in the office of a GP"]. Practicus 6(4): 152-153.

29. Vojtíšková J (2006). Kompetence všeobecné sestry v ordinaci praktického lékaře. [Competences of a registered nurse in a general practitioner's office]. Medicína pro praxi 2: 94-96. [online] [cit. 2019-03-28]. Available from: https://www. medicinapropraxi.cz/pdfs/med/2006/02/12.pdf 